\title{
Using Gastronomy Heritage as a Part of Lifestyle Studies
}

\author{
By Kristina Zábrodská*
}

\begin{abstract}
The food and drinks we consume and the ways in which we do this form our every day life and national identity. The choice of the ingredients, their preparation and serving is based on the past, on the experience of our ancestors. It is mostly passed on by word, repetition, old cookbooks and handwritten recipes. In the time of their origin, newspapers were the most testified source of information of everyday life. If we want to depict the old lifestyle, we have to look in newspapers and magazines from that time. The question is the method. Lifestyle research focuses on social relations and positions in society. Its methods include mostly interviews, focus groups, field research and questionnaires. These methods can't be used in the history research. On the grounds of the research of three Czech daily presses and eight Czech women's magazines from the period 1918-1938, as well as Carlo Ginzburg's microhistory, I developed my own research method for studying Czech gastronomy in the First Independent Czechoslovak Republic of 1918-1938. The analysis showed a dramatically different reality than is believed and transmitted to the next generation. And it build a bridge to other nations in the same period of time.
\end{abstract}

Keywords: Gastronomy, methodology, lifestyle studies, Czech history, tourism

\section{Introduction}

As the food movement is getting bigger around the world, there started to be a very popular the gastronomic tours through the history or the gastronomic tours depicting the foreign culture. Czech Republic is not an exception and incoming tourists can find various tours on beer, Czech local food or Czech traditional food. Do the guides show the true Czech gastronomy?

In the past eight years Czech chefs and the public started to rediscover national Czech cuisine. It was not the unhealthy, old, fatty cuisine anymore, but national and traditional cuisine representing Czech heritage and the golden age of the first independent Czechoslovak Republic in 1918-1938.

The meal was presented as a part of the Czech culture, a tangible image of the old good days with all the good characteristics of people from that timefairness, loyalty, gentility and good manners. Chefs started to present typical Czech dishes in both traditional and modern ways; food journalists have written articles praising these chefs and their food; the era 80 years ago is now seen as the golden era when the nation found its roots. However, most of the news was not based on the historical perspective or facts; rather, it presented the writers wishes and hopes, instead of the proven truth.

\footnotetext{
* $\mathrm{PhD}$ Candidate, Institute of Communication Studies, Faculty of Social Sciences, Charles University in Prague, Czech Republic.
} 
That was one of the reasons for choosing this research. There were no such studies on this theme, and therefore the methodology was also missing. I had to find out the proper method for depicting the image of the past and for exploring the daily life or lifestyle of our ancestors, without the possibility of using standard lifestyle studies methodologies of today. My focus is on the print media from that time, so I looked into media studies methodology and combined it with historical research.

\section{Setting out the Field}

Researchers began to acknowledge gastronomy studies in the 1980s, especially everyday historians. Historians, ethnographers, and anthropologists focused on the history of gastronomy and eating, on eating habits across time and various cultures, on the origin of dishes and changes of cookbooks, and put these themes into wider studies of everyday life. The shift of the research's theme has been shown in Peter Burke's book What is Cultural History?, the cornerstone of social history and historiography. The change in this paradigm is approved by various other books, studies, and popular publications. Bob Ashley, Joanne Hollows, Steve Jones and Ben Taylor focused in their book Food and Cultural Studies (2004) on the interdisciplinary history of food studies from the perspective of cultural studies: "From the semiotics of Barthes and the anthropology of Lévi-Strauss to Elias's historical analysis and Bourdieu's work on the relationship between food, consumption and cultural identity" (Ashley, Hollows, Jones \& Taylor, 2004, p.1). They try to convince the reader of the legitimacy of food and consumption research.

In the 1970s and 1980s, the lifestyle research moved to the focus of scholars. It now refers to all parts of life and includes various sciences anthropology, philosophy, sociology, ethnography, semiotics, linguistics, history, cultural studies, and also media studies.

History studies various issues, from sociology to economy and politics. Its field of study intersects with different sciences, which can complicate its unique classification within the social sciences. It might be, however, that natural development of the study and certain interdisciplinary growth will be more useful for precise research of the past.

Historical anthropology focuses on culture, including groups of people following the same norms, having the same lifestyle, living in the same time and place, and communicating with the same language (Budil, 1999, p.13). "Anthropology has become in relation to sociology or history more auxiliary science, serving the scientist as a source of influence or characteristics of the natural, cultural and social milieu of the men," (Wolf, 1999, p.92).

Historiography describes "the writing of history based on the critical examination of sources, the selection of particulars from the authentic materials, and the synthesis of particulars into a narrative that will stand the test of critical methods." (Historiography, 2013, online). A historiographer presents a story based on research of various sources that fit in other stories and known 
history. The important events are more often completed with descriptions of daily life. The depth of the image is in direct proportion with the variety of the sources coming from various science fields. The sources are not the mirror of history, but rather an interpretation within a particular time (of origin). It depends on their characteristics, origin and also the reason of origin, for example whether it is a state issue, personal correspondence, or memoirs.

In the second half of $20^{\text {th }}$ century, microhistory ${ }^{1}$ arose from the anthropology and sociology methodologies in order to survey the life of the single person or small part of the society, mostly that which is territorially specified.

The main representative of this field, Carlo Ginzburg, showed the basic principles and the overarching idea in his work The Cheese and The Worms (1976) when he described the life of one Italian miller and his mental world in 16th century with common history research methods. He put the same emphasis on the life of an ordinary man as others put on researching important historical events. He has set a counterpoint to the history of winners. Carlo Ginzburg tells this story like journalists write articles or authors build up their novels. This unusual narrativity in history research has been noticed by Giovanni Levis, who ascribes it two main functions: first, it shows "the true functioning of certain aspects of society," (Levis In Hiebl, Langthaler, Jahrbuch für Geschichte des ländlichen Raumes, 2012, p.13) and second, it display the behaviours of individuals, with their contradictory intentions and actions, and places these in relative terms to the "absolute position of the researcher, while looking within the research process and exposing issues - the source pool, the interpretation and the presentation." (Levis In Hiebl, Langthaler, Jahrbuch für Geschichte des ländlichen Raumes, 2012, p.13) Narrativity, as a denial of hard statistics and pure data descriptions, has been asserted also by Lawrence Stone and Haydn White, who put it one step further by analysing diaries and private sources and describing the history in them as a novel.

Carlo Ginzburg represents the part of microhistory as a history of one man. Similarly, the main microhistory representative of Germany, Alf Lüdtke, put the everyday life of individuals in a society in focus. "The link between behaviour and the meaning, focus on the class and culture, is the theme of everyday history. It permits to examine the norms, attitudes and behaviour of certain group of people and associate them according of the same characteristics in socials groups or classes," (Lüdtke, 1989, p.24).

\footnotetext{
${ }^{1}$ Microhistory as scientific discipline was described. Winfried Schulze alerts, that the concept was firstly described by Fernand Braudel in 1960 (Schulze, 1994, p. 40), but already Friedrich Nietzsche was in 1882 in Die fröhliche Wissenschaft thinking, why is nobody researching the history of every day issues (Pickl, Feigl, 1992, p. 11).
} 
Jürgen Schlumbohm has likened microhistory to a view through a microscope, or high-scale observation. "From the beginning there was a requirement to observe with this method the main phenomenon in the past, which have been left out yet," (Schlumbohm, 1998, p.20). From this point of view, it is clear why the first microhistory studies focused mostly on the lower classes. The focus has not been put on the individual alone, but furthermore on his social milieu and the relationships and life strategies he employs. "Social groups and institutions aren't shown as an objective condition, but as a part of everyday life shaped by the individuals, the 'small men,' in the struggles, conflicts and their solutions through the politics of everydayness, which is based on the strategic use of the social rules," (Schlumbohm, 1998, p.22). In Germany, labels such as Everyday History, Historic Anthropology and from the 1970s Micro Social History, Neue Social History or History Nouvelle are employed more often. The concept of Historic Anthropology is popular also in American studies. Microhistory (mostly in Italy, Germany) and Historic Anthropology (more in USA, France, Germany) can be seen as two thought tendencies and methodologies within the research of everydayness in the past.

Finally, Schlumbohm emphasises the importance of using the micro- and macro- point of view on historical events. The key issue in historic anthropology is the idea of everydayness, because it shows the regularity, dynamics and behaviour patterns of every common day (see Sider In Davis, Lindenberger, Wildt, 2008, p.121). Everyday activities, specifically habits and rituals, are very important because they form the culture. Most scientists define the research field of historic anthropology and its related fields, but they don't discuss the method. The discussion describes the differences between social history, historic anthropology, cultural anthropology, everyday studies, and microhistory. Peter Burke in 1987 set out the criteria for how to distinguish historic anthropology from social history: qualitative case studies, spatially marked research field, the method of "tight description," analysis of the rituals maintaining the world continuum and the link to anthropological and cultural theory (see Tanner, 2004, p.20-21). A man and his world, or the society in general, stands in the focus of historic anthropology. Historic anthropology derives the desired information from "outside sources," for instance what was written about the men/society. On the other hand, this paper focuses more on the "inside sources," for instance what the society published about itself in the media from that time. Therefore the proposed methodology of historic anthropology is not useful in this research, although the fields of the study are quite overlapping.

If we want to realize how life patterns exist, we have to look at it closely or even try to live it. Looking in the past, we have to search for as much evidence of everyday situations and ideas of men as possible. Everyday events consist of various smaller or bigger events, in which every person acts in a different way according to their personal characteristics, education, and life experiences. "Everydayness outlines more the research programme, which focuses on the diverse praxis the men perceive the situation and react on it," 
(Davis, Lindenberger, Wildt, 2008, p.15). In other words, this best depicts the lifestyle.

\section{Methodology}

The term lifestyle indicates the way of living of a person or a particular group. It is defined by certain habits, expectations, norms and behaviour patterns that are regularly repeated and easy to identify. Lifestyle is a system of culture, which defines a particular social group. This shows one of the basic matters of lifestyle studies. According to action theory in social psychology, our setting forms our behaviour in situations, and cause and effect are in unison, but in reality we have more inputs than just our norms or setting when involved in decision-making (see Lebenstil/Lebenstilforschung, 2011, p.12). Furthermore, there is no conclusion on the specific definition of lifestyle; rather, it is described from various points of view, containing quite often the people's behaviour. "One of the most important containments can be taken if we define lifestyle as a pattern of behaviour, belonging together and being stable for certain time" (Lebenstil/Lebenstilforschung, 2011, p.37)

How different lifestyles are depicted depends on method. Lifestyle research $^{2}$ focuses on social relations and position in the society. Especially in Germany and in the Anglo-Saxon territory, lifestyle studies focus on diverse social groups, points of social inequality, and subcultures. Its methods include mostly interviews, focus groups, field research, and questionnaires. The researchers mostly describe the situation or the culture. It is obvious that lifestyle is tightly connected with class, age, education, gender and income. Lifestyle is based on daily routines and behaviour patterns and, as such, can be investigated with the methods of everyday studies or anthropology. In addition, lifestyle studies contain also the norms of the time, including what is good and what is bad. This is reflected in the used language, so semantic analysis, or at least content analysis, of written or spoken messages should not be excluded.

Lifestyle studies are related to ethnography, which can also be used in history research. David Machin describes ethnographic research for media studies and suggests exploring how people relate to the mass media:

"This ethnographic gaze involves carrying out something we will call a reassembled ethnography. This term refers to the way that, after we have recorded data, or we might say, disassembled it from the flow of everyday life; we must then undertake a corresponding work of reassembly, so that the interesting and relevant details are set back into the flow of experience on the small and large scale. The small scale would be the immediate setting of social interaction and the large scale would be the larger available cultural repertoire." (Machin, 2002, p.3) He perceives ethnography as depicting the life and image of society by way of depicting one's behavior and understanding his/her motivation.

\footnotetext{
${ }^{2}$ Most of the studies focus on consumer behaviour, marketing strategies and subcultures, what is for this paper absolute irrelevant and therefore not mentioned.
} 
Methods of modern lifestyle studies are totally useless in historical research. The historian has to look into "dead sources," for example in diaries, letters, notes, books and media published during the period under investigation. They describe the important issues of the past and show what was important for people, including what belonged to pop or mass culture and what was perceived as unusual.

Twenty years ago, in September 1995, an international symposium in Častá - Píla was held focusing on Everyday Life in the Cities in Middle Europe from the Middle Age to the End of $19^{\text {th }}$ century. The scientists discussed methods of researching life in the past and came to the conclusion that everyday life methodology has developed very little since its birth in the 1970s. There are still two main questions left unanswered: the theory background and the methodology. "Consistent answers to these two issues aren't possible as they are characterised through the intuition diversity and difference in understanding and approaches of each author," (Čičaj, Pickl, 1998, p.9). The studied theme determines the method. Lifestyle implies so many different issues and topics, that the only possibility of how to depict it is to combine more than one suitable method. That makes the research unique.

\section{Research Design}

From the research of three Czech daily presses and eight Czech women's magazines from the period 1918-1938, as well as Carlo Ginzburg's microhistory and methodologies used in history research and other fields of social sciences (like everyday studies, social anthropology, ethnography) I developed my own research method and carried out a study of Czech gastronomy in the first independent Czechoslovak Republic in 1918-1938. The analysed titles should cover the whole audience, all classes, the cities and the countryside, and therefore it could be supposed that the analysis shows the everyday life in Czechoslovakia at that time.

Food, including its consumption and preparation, is a part of everyday life, and so part of lifestyle studies. I chose this theme six years ago when the popularity of the first Czechoslovak Republic started to rise and chefs and journalists promoted a rebirth of traditional Czech cuisine referring to this time. However, the complex publication about the food culture and Czech cuisine in 1918-1938 is missing, so I decided to depict it. The main sources are cookbooks from that time, but we can't be sure if the people really cooked and ate the meals or if they could actually afford them. Another piece of information can be found in memoirs, books dealing with the history of everyday life, folklore studies and lastly, historical press. I looked for evidence in the newspapers, the three most influential dailies (agricultural Venkov, democratic - government Lidové noviny and social democratic Národní listy) and the eight most popular women's magazines (social democratic and later communist Žena, labour Ženské noviny, middle class Ženské listy, social democratic weekly Ženský list, apolitical Ženský svět, magazine for household 
Česká Žena, communist Rozsévačka and calendar Kalendář paní a dívek Československá žena).

In the $20 \mathrm{~s}$ and $30 \mathrm{~s}$, people believed in the press, and it was the most popular mass medium. Old newspapers give the past vividness and revive historical events. They give us evidence about the mood, the issues and everyday life of various social classes in that time.

I used content analysis to depict the themes, frequency, authors, tendencies and differences between the periodicals according to their political affiliation or readership. The explored articles dealt with food, drinks or consumption, gastronomy at all (the economic and agricultural news and the advertisement are not included because of the huge amount of the articles and also quite big repetition of the themes). The analyzed period is based on the important religious holidays and traditions according to the agricultural year and Christian and rural feasts (New Year, $6^{\text {th }}$ January (Three Kings Day), Carnival, Easters, $1^{\text {st }}$ May, Mother's Day, harvest, $11^{\text {th }}$ November (feast of St. Martin traditional duck backing), $6^{\text {th }}$ December (St. Nicolaus), Advent and Christmas). First Czechoslovak Republic lasted 20 years, so I haven chosen just eight significant years for its development (1918, 1919, 1921, 1924, 1929, 1933, 1935 a $1938^{3}$ ).

For further findings of additional and linking facts, the historical analysis method was used as well - looking in the statistics, history books, memoirs, microhistory publication about small cities. The aim is to define the First Republic's gastronomic journalism. It answers questions about the development of the First Republic journals' coverage of this subject, about the presentation of gastronomic subjects in particular titles and the differences in media approach in charged moments in accordance with their orientation. Attention is paid to a description of gastronomical habits of different social classes in cities and villages over different periods of the year.

Content analysis is broadly used for the research of media content, news or articles selected with certain aims. In this research the analyzed articles are selected according their gastronomy theme either in the headline or in the section, so I supposed, the selected and analyzed article referred to the gastronomy. I combine the quantitative approach with the qualitative one. Statistical analysis is combined with the text interpretation and search for the themes. Collected data were processed with SPSS and Microsoft Excel.

The research questions should depict the former gastronomy journalism and show us what our ancestors ate.

\footnotetext{
${ }^{3}$ In 1918 the Czechoslovak Republic was founded. In 1919 the post war and the independency euphoria was replaced by hunger, lack of supplies and income. In 1921 the economy has started to flourish and the state was stable. In 1924 the economy was booming, this time is called the golden age. In 1929 the Great Depression has reached Czechoslovakia and the unemployment rate and hunger has risen. In 1933 the bad economic situation got even worst and the political scene was attacked by the rising power of the Nazi party. In 1935 the fascist have gained quite a lot voices in the votes and Edvard Beneš became president and in 1938 the Munich Act came and Czechoslovakia was destroyed.
} 
1. What gastronomy themes did the journalists focus on in the three most influential everyday press and eight women magazines in the years 1918-1938? What genre did they choose and how often were the articles published?

2. Did the news coverage differ in the press according to its political affiliation? Are there specific sections for this type of news?

3. Does the selection of gastronomy news correlate with the political and social development?

4. Is it possible to trace the social, economical and political development in Czechoslovakia in 1918-1938 according to the gastronomy articles? How did the picture of gastronomy change and develop during that time?

5. How does gastronomy journalism change in the particular medium?

On the ground of these research questions I have defined the hypotheses, which content analysis proved to be true.

H1. Issues of gastronomy journalism were the same as the discussed themes in the social situations in the first independent republic.

H2. Among the most common themes were information about food, nutrition, daily meals, food supply and recipes.

H3. Articles about restaurants were quite rare, as mostly only rich people had time and money to visit them. The others used to go to the cafés or pubs, where they got something to drink and a snack.

H4. Most of the articles contained recipes and instructions how to cook or prepare some meal. Some introduced new technologies.

H5. According to the media has the gastronomy journalism varied - in themes and genre.

Historical analysis is based on the idea that history is not made of unique events, but of a sequence of events, people's behavior, and ideas. The key to its understanding is the interpretation and the researcher, who defines the sources, leads the investigation, interprets the findings, and puts them in a broader field. "Based on the study and analysis of the gained findings from literature and other sources is the history reconstructed and the author creates a synthesis and conclusions" (Vaculík, Čapků, 2004, p.53).

In this analysis I have used the combination of direct and indirect methods - the analysis of the press, magazines and cookbooks from that time and the analysis of indirect sources like statistics, yearbooks, memoires, history books. These methods are completed with the induction, deduction and the historic demography. So I can answer not just the question What did happened? But also Why and How? At this point it must be mentioned, that press is actually not the best primal direct source, because it is not absolutely independent. The news are selected and written in a specific way according to the various interests of the owner or political or social climate in society. The news is more taking a stand than objective. „Newspapers and magazines used to fulfil two 
main goals - to inform and to deliver news and at the same time they also struggle for idea making and political influence. The significant character of the press is the information, although often it means the explanation of facts. The necessity of this explanation is based in the nature of information and explanation is actually the demonstration of certain attitude or opinion." (Bůžek et col., 1994, p. 45) I have tried to balance this disadvantage by looking in the press of the whole political spectrum. In the 20 s and 30 s the political press was quite strong and influential and readers were quite stable. They were structured in the social classes and could be described according their differences. In the time of its origin the newspapers were the most testified source of information of everyday life. If we want to depict the old lifestyle, we have to look in the newspapers and magazines from that time.

The emphasis on the media analysis makes this research unique, because it focuses on a historic theme with media studies methodology. But I suppose that in this interdisciplinarity lies the strength and it opens the research possibilities.

\section{Gastronomy Journalism 80 Years Ago}

The aim of this text is not to describe the gastronomy and eating habits in the Czechoslovakia in 1918-1938, but to discuss the methodology on the example of the research of this theme. Therefore the results are presented very briefly.

The analysis contains 900 articles in 11 press media and proved that the Czech press was interested in gastronomy. Media, according to their bias and reader, reflected the current situation - the daily newspapers wrote about daily supplies, labor press emphasized the poverty, far too expensive products and insufficient sustenance of labor force in commented news coverage. Women's journals brought plenty of recipes, tips and hints on making housekeeping easier, and they also paid attention to dining and news on cooking and alimentation.

Daily press and the women's journals have own section ${ }^{4}$ for the gastronomy news. Get to know more about the authors wasn't possible, because the news and articles were mostly unsigned.

Press has formed the opinion of public and partly their eating habits, but especially in the first years after the war most people made the decision what to buy not by their taste but by the money, they can afford to spent on it. In the golden age in 1923-1928 most of the people didn't suffer with hunger and they

\footnotetext{
${ }^{4}$ Národní hospodár, Zásobování, Domácnost (Lidové noviny), Národní hospodář „Venkova“, later Hospodářství, Žena - Domov (Venkov), Otázky zásobování a výživy (Národní listy). Domácnost a hospodářství, Kuchyně, Co vařit / Co vařiti? (Ženské noviny), Pêle-mêle (Ženský svět), Domácnost a hospodářství, Ze ženského světa, Praktické pokyny, Rozmanitosti, Domácí hospodaření, Kuchyňka or Drobnosti (Žena), Rady pro domácnost, after 1928 Dobré rady and Naše obědy, later Kuchařské předpisy (Česká Žena), Rady pro domácnost, Rady pro naše maminky, Pro naše hospodyně and Dělnická domácnost (Rozsévačka).
} 
eat enough food, but the nutrition remained quite poor because of insufficient knowledge of all vitamins and nutrition facts. People used to eat mostly bread, flour products, potatoes, sometimes rice, pasta and cooked vegetable, meat was quite rare - at least once a week on Sundays. After the Great Depression food has become expensive and lot of people were due to the loss of the job hungry and never ate enough.

The analysis showed dramatically different reality than is believed and transmitted to our generation. It showed the past reality.

The other realized aspect was the influence of the gastronomy from other regions. Between the world wars belonged Prague, the Czech capitol, with Paris, Berlin and Vienna to the main European cities with high political influence and high living standards. Wealthy travellers can afford getting everything they wish - from champagne and oysters to fresh fish and extra ordinary local beer and white. The most quality products were exported from Czechoslovakia to other European countries and even to America (e. g. wine, spirit, Prague ham, beer, snails etc.). Food and drinks connected the world than as today. At the same time the business travellers brought the products from the other countries to Czechoslovakia and some of them started to be produced there (e.g. manufacturing of cocoa and coffee beans). Other important source of innovation represented the servants - boys and girls who went especially to Austria and Germany to work as a household maids, household cooks, babysitters, craftsman and specialised teachers, who returned back to Czechoslovakia once or twice a year with a knowledge of new products, ingredients, tastes and combinations. They all formed the traditional Czech cuisine, which is nowadays reconstructed and rediscovered by the popular food guided tours and presented as a Czech culture.

\section{Conclusion}

Looking in the past and exploring the "good old life" has become in the last years quite popular. The research of the old lifestyle is though not so easy and straight. It includes many disciplines - like anthropology, ethnography, sociology, microhistory, history studies and media studies and of course lifestyle studies. Each field has its own methodology and uses different methods. Their combination and adaptation leads to the desired results.

I study the gastronomy in the first independent era of Czechoslovak Republic in 1918-1938 according to the newspapers and women's magazines from that time. I combine the quantitative and qualitative content analysis with the microhistory and historical analysis and try to depict the old lifestyle and eating habits of our ancestors.

The biggest problem I have faced my whole research is the absent methodology and complex publication to the theme, but taken as advantage, I could have developed it on my own and I tried to reflect the process in this text. 
The results contributed to the knowledge about the past cuisine, Czech tradition and culture and can be transmitted and presented to the tourists, who may realize, that their culture and experience had something in common with the Czech ones.

\section{Acknowledgements}

I would like to thank Doc. PhDr. Barbara Köpplová, CSc. for the valuable advices and endless enthusiasm in the theme. This text was produced with financial support from the project GAUK Nr. 1638314 and from the project Specifický vysokoškolský výzkum SVV IKSŽ FSV UK 260343.

\section{References}

Adler, P. A., Adler, P., Fontana, A. 1987. Everyday Life Sociology, Annual Review of Sociology, Vol. 13, p. 217-235

Ashley, B., Hollows, J., Jones, S., Taylor, B. (eds.) 2004. Food and Cultural Studies, Routledge, London and New York, ISBN 0-415-27038-3

Budil, I. T. 1999. Mýtus, jazyk a kulturní antropologie, Triton, Praha, ISBN 80-7254$001-7$

Burke, P. 2008. What is Cultural History?, Polity, ISBN 0745644090

Bůžek, V. and col. 1994. Úvod do studia historie, Pedagogická fakulta Jihočeské univerzity, České Budějovice, ISBN 80-7040-063-3

Čičaj, V., Pickl, O. (eds.) 1998, Städtisches Alltagsleben in Mitteleuropa vom Mittelalter bis zum Ende des 19. Jahrhunderts, from International Symposion in Častá-Píla in 11.-14. September 1995, Academic Electronic Press, Bratislava, ISBN 80-88880-21-1

Davis, B., Lindenberger, T., Wildt, M. (eds.) 2008. Alltag, Erfahrung, Eigensinn. Historisch-Anthropologische Erkundungen, Campus Verlag, Frankfurt/New York, ISBN 978-3-593-38698-0

De Vries, J. 2013. The Return from the Return to Narrative, Max Weber Programme, European University Institute, Lecturer No. 2013/01, ISSN 1830-7736, DOI= http://c admus.eui.eu/bitstream/handle/1814/25278/MWP_LS_DeVries_2013_01.pdf

Eibach, J., Lottes, G. (eds.) 2002. Kompass der Geschichtswissenschaft, Ein Handbuch, Vandenhoeck und Ruprecht, Göttingen, ISBN 3-8252-2271-3

Fay, B. 2002. Současná filosofie sociálních věd, multikulturní přistup. Slon, ISBN 80$86429-10-5$

Ginzburg, C. 1980. The Cheese and the Worms. The Cosmos of a Sixteenth Centruy Miller, Baltimore, ISBN 0-8018-4387-1

Hiebl, E., Langthaler, E. (eds.) 2012. Im Kleinen das Grosse suchen, Jahrbuch für Geschichte des ländlichen Raumes 2012, Studien Verlag, ISBN 978-3-70655216-5

Kuhn, T. S. 1996. The Structure of Scientific Revolutions, University of Chicago Press, ISBN 0-226-45808-3

Lüdtke, A. (eds.) 1989. Alltagsgeschichte Zur Rekonstruktion historischer Erfahrungen und Lebensweisen, Campus Verlag, Frankfurt am Main/New York, ISBN 3-59333893-9 
Machin, D. 2002. Ethnographic research for media studies, Hodder Arnold, ISBN 978-0340806876

Pickl, O., Feigl, H. (eds.) 1992. Methoden und Probleme der Alltagsforschung im Zeitalter des Barock, Verlag der Österreichischen Akademie der Wissenschaften, Wien, ISBN 3-7001-1990-9

Schlumbohm, J. 1998. Mikrogeschichte- Makrogeschichte komplementär oder inkommensurabel? Göttinger Gespräche zur Geschichtswissenschaft, Band 7, Max-Planck-Institut für Geschichte, Göttingen, Wallstein Verlag, ISBN 3-89244321-1

Schulze, W. (eds.) 1994. Sozialgeschichte, Alltagsgeschichte, Mikro-Historie. Eine Diskussion, Vandenhoeck und Ruprecht, Göttingen, ISBN 3-525-33593-8

Sider, G. 2008. Anthropology, History, and the Problem of Everyday Life: Issues from the Field and for Discussion. In Alltag, Erfahrung, Eigensinn: HistorischAnthropologische Erkundungen, Davis, B., Lindenberger, T., Wildt, M. (eds.), Campus Verlag, Frankfurt / New York, ISBN 978-3-593-38698-0

Tanner, J. 2004. Historische Anthropologie zur Einführung, Junius, Hamburg, ISBN ISBN 3-88506-601-7

Vaculík, J., Čapků, F. 2004. Úvod do studia dějepisu a historický proseminár̆, Masarykova univerzita, Brno, ISBN 80-210-3393-2

Wolf, J. 1999. Člověk a jeho svět. Úvod do studia antropologických věd. Základní antropologické otázky. Kulturní a sociální antropologie. Univerzita Karlova, Karolinum, Praha, ISBN 80-7184-871-9

Zábrodská, K. 2014. Životní styl za první republiky na přikladu gastronomie v českém dobovém tisku. Univerzita Karlova, Fakulta sociálních věd, Mediální studia a žurnalistika, Mediální studia, Praha, PhDr. thesis

Lebenstil/Lebenstillforschung. 2011. Kölner Zeitschrift für Soziologie und Sozialpsychologie, Sonderheft 51/2011, Wiesbaden, Westdeutscher Verlag

Historiography. 2013, Merriam Webster Dictionary, DOI = http://www.merriamwebster.com/dictionary/historiography

Lidové noviny 1918, 1919, 1921, 1924, 1929, 1933, 1935, 1938

Národní listy 1918, 1919, 1921, 1924, 1929, 1933, 1935, 1938

Venkov, 1918, 1919, 1921, 1924, 1929, 1933, 1935, 1938

Česká Žena (1909 - 1927), later Naše domácnost (1927 - 1932)

Československá žena. Kalendár paní a dívek (1923 - 1936)

Rozsévačka (1926 - 1938)

Žena $(1919$ - 1925)

Ženské noviny $(1922,1930,1931$ a 1935)

Ženský list (1920 - 1922)

Ženský svět (1918 - 1930)

Ženské listy (1918 - 1926) 